\title{
Detection of Animal Products in Ruminant Feeds by Microscopy and Real Time PCR
}

\author{
Luciana Pacheco Golinelli ${ }^{1}$, Joab Trajano Silva ${ }^{1}$, Ana Carolina Carvalho ${ }^{1,2}$ and Vânia Margaret Flosi Paschoalin ${ }^{1 *}$ \\ ${ }^{1}$ Instituto de Química, Universidade Federal do Rio de Janeiro, Av. Athos da Silveira Ramos 149 Cidade Universitária, Zip-code 21949-909, Rio de Janeiro-RJ, Brazil \\ 2Universidade Federal do Rio de Janeiro-Campus Macaé, Av. Aloízio da Silva Gomes, 50-Granja dos Cavaleiros, Macaé-RJ, Zip-code 27930-560, Rio de Janeiro-RJ, \\ Brazil \\ "Corresponding author: Vânia Margaret Flosi Paschoalin, Instituto de Química, Universidade Federal do Rio de Janeiro, Av. Athos da Silveira Ramos 149 Cidade \\ Universitária, Zip-code 21949-909, Rio de Janeiro-RJ, Brazil, Tel: +552139387362; Fax: 552139387266; E-mail: paschv@iq.ufrj.br \\ Rec date: Mar 16, 2016; Acc date: Apr 11, 2016; Pub date: Apr 13, 2016 \\ Copyright: ( 2016 Golinelli LP, et al. This is an open-access article distributed under the terms of the Creative Commons Attribution License, which permits unrestricted \\ use, distribution, and reproduction in any medium, provided the original author and source are credited.
}

\begin{abstract}
This study evaluated the performance of the TaqManTM real- time PCR assay to detection of DNA from not allowed-animal derivatives in reference feeds samples. The results of qPCR were compared with the microscopy, only method validated to control the presence of animal proteins, according the European Communities. The qPCR tests targeting $12 \mathrm{~S}$ rRNA from cows, sheep, porcine and chickens and cytochrome $\mathrm{b}$ region from caprine in feeds were able to detect half the amount $(0.0125 \% \mathrm{w} / \mathrm{w})$ of meat-and-bone meal (MBM) that could be detected by microscopy in samples spiked with MBM. Although cross-contamination in feeds and food processing plants is an unexceptional problem, the presence of traces of prohibited animal products in feedstuffs is an alert to potential impact on herd and human health, because it has been associated with the transmission of transmissible spongiform encephalopathy (TSE). These results indicate that a combination of qPCR tests and microscopic analysis could be used to ensure the safety of feedstuffs, allowing the identification of the animal species of the derivative and even the kind of tissue added to the feed, providing useful information for sanitation inspection authorities in this country.
\end{abstract}

Keywords: Feeds for ruminants; Meat-and-bone meal; Mammalian and avian species-specific identification; Microscopic analysis; Realtime PCR tests

\section{Introduction}

Brazil is a major producer and exporter of many agricultural products (AAFM). According to the Brazilian Ministry of Agriculture, Livestock and Food Supply (MAPA), the cattle industry and its derivatives are a major component of world agribusiness. During the twenty-first century, Brazil has become the largest exporter, secondlargest producer, and third-largest consumer of beef [1]. The country has the second largest herd, with over 212 million cattle heads, and, in 2004, Brazil took the lead in meat export, since one-fifth of the meat sold to over 180 countries in international markets originated from Brazil $[2,3]$.

In Brazil, pastures are the most economical source of food for feeding beef and dairy cattle, and $88 \%$ of the beef produced is grass-fed [4]. During the dry season the significant reduction in production and nutritional value of pasturage causes animal weight loss or low milk production, so confinement may be an option to provide a more balanced diet, using a supplement for ruminant feed [5]. Use of commercial feed is advisable if the increased production increases profitability, that is, when the increased cost of commercial feed is offset by increased profits [6].

Two aspects of sanitation restrictions are important for Brazilian beef exports: foot and mouth disease (FMD) and bovine spongiform encephalopathy (BSE, or mad cow disease) [7]. Transmissible spongiform encephalopathies (TSEs) are a group of rare degenerative brain diseases, usually fatal in humans and animals, with a long incubation period; currently no treatment for any of these diseases exists. TSEs in animals include scrapie in sheep and goats, bovine spongiform encephalopathy (BSE), feline spongiform encephalopathy (FSE), transmissible mink encephalopathy (TME) and chronic wasting disease (CWD) found in deer, elk and moose populations. In humans, the most commonly known TSE is Creutzfeldt-Jakob Disease (CJD) $[8,9]$. A new variant of Creutzfeldt-Jakob disease (vCJD) that affects young individuals may be caused by transmission of BSE to humans through consumption of infected beef [10].

The occurrence of BSE in cattle and its transmissibility to humans has become an international concern and requires global strategies to reduce human exposure to the disease through appropriate food quality control practices [8]. The World Health Organization (WHO), the World Organization for Animal Health (OIE) and the United Nations Food and Agriculture Organization (FAO) have recommended protective measures such as: (i) all animals at risk must be culled and disposed of, as well as products derived from these animals; (ii) the removal of specified risk material (SRM) from cattle, sheep and goats, to prevent the material from entering the food and feed chain; (iii) a ban on the use of processed animal protein (PAPs) in feed for farm animals; (iv) the establishment of procedures for surveillance and notification of BSE occurrences to health authorities in all countries [11].

According to the OIE, Brazil is a member of the "Negligible" risk group for BSE, the safest category [12]. Brazilian Ministry of Agriculture, Livestock and Food Supply (MAPA), allows the marketing of calcined bone (without proteins and fats), milk and milk products, and gelatin and collagen, prepared exclusively from hides and skins [13]. The banned animal materials can be detected by various analytical methods, such as microscopy capillary isoelectric focusing [14], enzyme-linked immunosorbent assays and near-infrared microscopy (NIRM) [15,16], as well as the identification of species- 
specific central nervous tissue by gas chromatography-mass spectrometry (GC-MS) [17]. Microscopic analysis is the official method for the detection and characterization of PAPs in feedstuffs, as established by the European Union (Commission Regulation EC/ 152/2009), which includes both the observation of morphological conformation of rough fragments with a stereomicroscope and the examination of histological structures of fine particles with a light microscope [18].

Molecular assays, such as conventional PCR and real-time quantitative PCR (qPCR), are more sensitive, specific and reproducible, and the latter allows for the semi-quantification of nucleic acids, especially when a fluorescent probe is used for detection of a specific PCR product, such as TaqMan qPCR, an automated technology with lower turnaround times $[15,19,20]$.

The present study investigated the presence of prohibited animal products in commercial feeds obtained in the retail market of two Brazilian regions traditionally involved in livestock activities. Twentynine samples of commercial bovine feeds were evaluated by two methodologies: microscopy analysis and qPCR assays for the speciesspecific detection of ruminant, porcine and avian (chicken) mitochondrial DNA in bovine feeds.

\section{Materials and Methods}

\section{Reference sample preparation and samples control}

Reference samples free of animal material or meat-and-bone meal (MBM) were formulated at the laboratory. Fifteen grams and reference feeds were processed and homogenized by the paper cone riffler splitting method. The macroscopic and microscopic aspects of each feed and bovine MBM reference samples were evaluated. MBM-free feeds were spiked with increasing proportions of $\mathrm{MBM}$, from 0.0125 , $0.025,0.05,0.10,0.20,0.40$ to $0.80 \% \mathrm{w} / \mathrm{w}$, to obtain feeds with known amounts of animal-derived products. Three samples of each spiked feed were prepared as described by Sanches et al. and were tested in a blind analysis, where the spiked-feeds were coded and randomly distributed during assays [21].

Blood samples from cow, goat, sheep, pig and chicken were used as species-specific controls. Corn (maize) and soybean grains were used as endogenous controls, since Brazilian animal feeds are composed mainly of these grains.

\section{Microscopic analysis and confirmatory tests}

Animal materials were detected by microscopy as described previously by the Brazilian Ministry of Agriculture, Livestock and Food Supply (MAPA), based on the morphological characteristics of different animal tissues, including bones (after rendering $133^{\circ} \mathrm{C}$ and 3 bars for $20 \mathrm{~min}$ for sterilization), muscle fibers, cartilage, and ligaments [2]. Parts of organs, skin, and other soft tissues are generally absent, or if present, barely detectable [22]. Qualitative chemical analyses were performed as confirmatory tests [23-25].

\section{DNA extraction and quantification}

Total genomic DNA was obtained from $100 \mathrm{mg}$ of commercial, reference and spiked feeds from the blood of different vertebrate species, corn and soybean, and MBM-containing and MBM-free feeds. DNA templates were prepared using a DNeasy Blood and Tissue Kit (Qiagen, Hilden, Germany), according to the manufacturer's instructions. DNA concentrations were estimated by use of a Qubit fluorometer (Life Technologies- Invitrogen Corporation, Carlsbad, CA, USA).

\section{Primers and probes}

The set of primers and probes used in this study are displayed in Table 1 . The probes were labeled on the 5 '-end with the fluorescent reporter dye 6-carboxyfluorescein (6-FAM) and on the $3{ }^{\prime}$-end with a non-fluorescent quencher (NFQ) and a DNA minor groove binder (MGB). Primers and probes were synthesized by Life TechnologiesInvitrogen Corporation, Carlsbad, CA- USA.

The specificity of each primer and probe set was tested against DNA templates targeting vertebrate species: cow, goat, sheep, pig and chicken. When the amplification plot did not cross the threshold and no Ct value was obtained ("undetermined"), a Ct value equal to 40 cycles was assumed for the assay [26].

\begin{tabular}{|c|c|c|c|}
\hline Species & $\begin{array}{l}\text { Primers and } \\
\text { probes }\end{array}$ & Sequences & Targets and references \\
\hline Capra hircus & $\begin{array}{l}\text { Forward Reverse } \\
\text { TaqMan Probe }\end{array}$ & $\begin{array}{l}\text { 5' - 5'- AAAGGACTTGGCGGTGCTT- 3' } \\
\text { 5' - 5'- TGACCTAACGTCTTTATGTGTGGTG-3' } \\
\text { 5' - 5'- (FAM)-TAGAGGAGCCTGTTCTATAATCGATAAACCCCG-(TAMRA)-3' }\end{array}$ & 12S rRNA gene. \\
\hline Sus scrofa & $\begin{array}{l}\text { Forward } \\
\text { Reverse } \\
\text { TaqMan Probe }\end{array}$ & $\begin{array}{l}\text { 5'- CTTGCAAATCCTAACAGGCCTG-3' } \\
\text { 5'- CGTTTGCATGTAGATAGCGAATAAC-3' } \\
5^{\prime} \text {-(FAM)- ACAGCTTTCTCATCAGTTAC-(NFQ)(MGB)-3' }\end{array}$ & $\begin{array}{l}\text { Mithochondrial cytochrome b } \\
\text { gene. }\end{array}$ \\
\hline Ovis aries & $\begin{array}{l}\text { Forward } \\
\text { Reverse } \\
\text { TaqMan Probe }\end{array}$ & $\begin{array}{l}\text { 5'-CCTTATTACACCATTAAAGACATCCTAGGT-3' } \\
5^{\prime} \text { - GGGTCTCCGAGTAAGTCAGGC-3' } \\
5^{\prime} \text {-(FAM)- ACTAATCCTCATCCTCATGC-(NFQ)(MGB)-3' }\end{array}$ & \\
\hline Bos taurus & $\begin{array}{l}\text { Forward } \\
\text { Reverse } \\
\text { TagMan Probe }\end{array}$ & 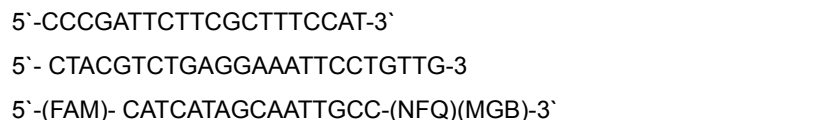 & \\
\hline
\end{tabular}


Page 3 of 7

\begin{tabular}{|c|c|c|c|}
\hline Gallus gallus & $\begin{array}{l}\text { Forward } \\
\text { Reverse } \\
\text { TaqMan Probe }\end{array}$ & $\begin{array}{l}\text { 5'-GAAATCGGTAGACGCTACGGA- 3' } \\
\text { 5'-GAAATCGGTAGACGCTACGGA- 3' } \\
5^{\prime} \text {-(FAM)-CAAATTCAGAGAAACCCTGGAA(NFQ)MGB)- 3' }\end{array}$ & \\
\hline $\begin{array}{l}\text { Zea mays and } \\
\text { Glycine max }\end{array}$ & $\begin{array}{l}\text { Forward } \\
\text { Reverse } \\
\text { TaqMan Probe }\end{array}$ & $\begin{array}{l}\text { 5'-TCTGGGCTTAACTCTCATACTCACC-3’' } \\
\text { 5'- GGTTACTAGTGGGTTTGCTGGG-3' } \\
5^{\prime} \text {-(FAM)-CATTCCTAACACTAGCCCTA-(MGB)-3' }\end{array}$ & $\begin{array}{l}\text { Chloroplast trnLintron } \\
\text { sequence Benedetto. }\end{array}$ \\
\hline
\end{tabular}

Table 1: Species-specific primer and probe sequences, targets and references used to Real-Time PCR assay.

\section{qPCR test conditions}

The qPCR tests using the TaqMan PCR Master Mix reagent (Life Technologies - Invitrogen Corporation, Carlsbad, CA, USA) were performed in a volume of $25 \mu \mathrm{l}$ in a 96-well reaction plate covered with Microamp (Life Technologies-Invitrogen Corporation, Carlsbad, CA, USA) using $900 \mathrm{nM}$ of each primer, $300 \mathrm{nM}$ of each probe and $10 \mathrm{ng}$ of DNA template. Reactions were performed in a Step One Plus ${ }^{\text {tix }}$ RealTime PCR System (Life Technologies-Invitrogen Corporation, Carlsbad, CA, USA) starting at $50^{\circ} \mathrm{C}$ for $2 \mathrm{~min}$ and at $95^{\circ} \mathrm{C}$ for $10 \mathrm{~min}$, followed by 40 cycles at $95^{\circ} \mathrm{C}$ for $15 \mathrm{~s}$ and annealing/elongation at $60^{\circ} \mathrm{C}$ for $1 \mathrm{~min}$. All qPCR tests were run in the same conditions, in triplicate.

\section{Sensitivity and linearity}

Calibration curves based on five points were constructed using measures in triplicate, corresponding to a 10 -fold serial dilution $(1$, $1: 10,1: 100,1: 1000$ and 1:10000) of $50 \mathrm{ng} / \mu \mathrm{l}$ of DNA template for each ruminant species and endogenous control. The standard-curve slope of -3.32 indicates a PCR reaction with $100 \%$ efficiency [27].

\section{Results and Discussion}

The specificity of primers and probes targeting porcine, bovine, caprine, ovine, and avian (chicken) material and endogenous controls was tested by screening the DNA templates from blood samples of each animal species and from corn and soybean against different animal species-specific qPCR systems. No cross-amplification was observed (Table 2).

TaqMan-qPCR tests were able to detect 500 pg of DNA templates from bovine, porcine, ovine, and caprine species and the endogenous controls, which corresponds to a $0.01 \%$ dilution from each DNA template. For the avian (chicken) sample, the minimum sensitivity was $50 \mathrm{pg}$, which corresponds to a $0.001 \%$ dilution of the DNA template. A test to determine whether a linear correlation between the amount of DNA template and the Ct was present was performed using DNA templates from corn and from the blood of each animal species. A plot test of the linearity Ct-values versus the logarithm of the DNA template amount indicated (Figure 1) a linear correlation for all species over four orders of magnitude. All curves showed a slope of - 3.5 except the curve for chicken, which presented a slope of - 3.2, very close to the theoretical value of -3.32. All species had R-squared values of 0.99 , indicating that accurate results and comparable efficiencies of $90 \%, 92 \%, 92 \%, 92 \%, 104 \%$ and $91 \%$ for the cow, pig, sheep, goat, and chicken samples and the endogenous controls, respectively, were obtained.

\begin{tabular}{|l|l|l|l|l|l|l|}
\hline Species & $\begin{array}{l}\text { Porcine- specific } \\
\text { PCR system }\end{array}$ & $\begin{array}{l}\text { Bovine- specific } \\
\text { PCR system }\end{array}$ & $\begin{array}{l}\text { Ovine- specific } \\
\text { PCR system }\end{array}$ & $\begin{array}{l}\text { Caprine specific } \\
\text { PCR system }\end{array}$ & $\begin{array}{l}\text { Avian } \\
\text { specific PCR system }\end{array}$ & $\begin{array}{c}\text { (chickendonous } \\
\text { control- } \\
\text { specific PCR system }\end{array}$ \\
\hline Capra hircus & ND & ND & ND & $22.0 \pm 0.0$ & ND & ND \\
\hline Bos taurus & ND & $23.0 \pm 0.1$ & ND & ND & ND & ND \\
\hline Ovis aries & ND & ND & $22.0 \pm 0.0$ & ND & ND & ND \\
\hline Gallus gallus & ND & ND & ND & ND & $21.4 \pm 0.1$ & ND \\
\hline Sus scrofa & $17.8 \pm 0.0$ & ND & ND & ND & ND & ND \\
\hline $\begin{array}{l}\text { Zea mays and Glycine max } \\
\text { (endogenous controls) }\end{array}$ & ND & ND & ND & ND & ND & $15.8 \pm 0.0$ \\
\hline
\end{tabular}

Table 2: Species-specific qPCR systems. Cross-amplification of DNA templates from each species was performed against others by using qPCR species-specific systems. Ct-values (mean and standard deviation) were obtained using $10 \mathrm{ng}$ of each DNA template from animal blood and endogenous controls. Triplicate PCR reactions were run from each DNA template. ND- animal material not detected (no positive signal after 40 qPCR cycles). 


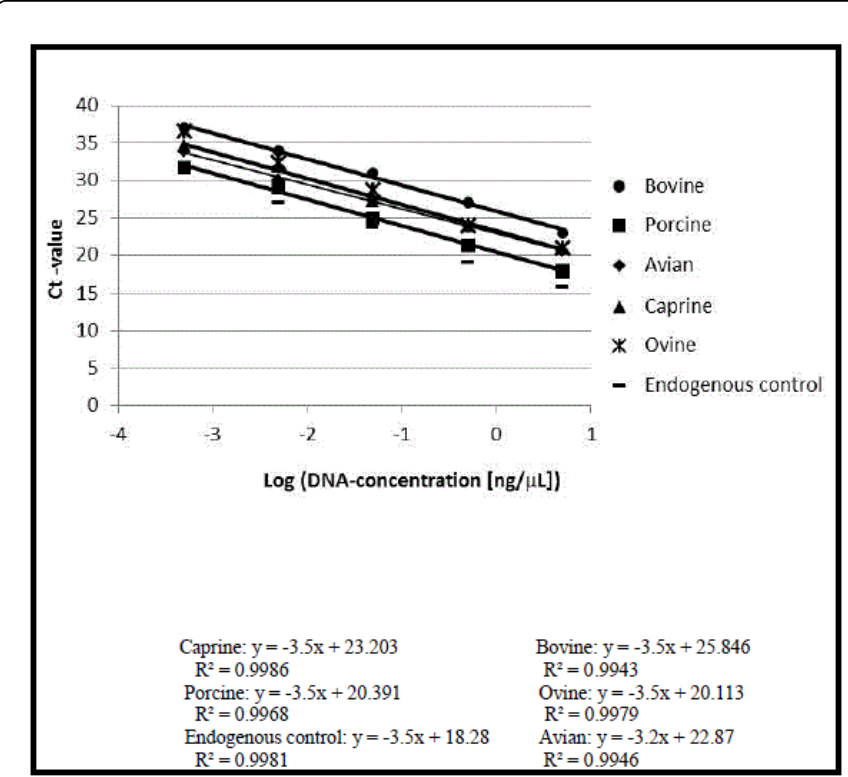

Figure 1: qPCR tests of 10 -fold serial dilutions of DNA templates from $50 \mathrm{ng} / \mu \mathrm{l}(100 \%)$ to $0.5 \mathrm{pg}$ obtained from blood samples of ruminant species (bovine, caprine and sheep), porcine, avian (chicken) and endogenous controls. Ct values obtained from reference samples of animal blood, corn and soybeans were plotted against the logarithm of DNA concentrations. The R-squared values and slopes were determined for each species. microscopic analysis, which is the official method used by Brazilian and European Union regulatory agencies. Samples spiked with $0.0125 \%(\mathrm{w} / \mathrm{w}) \mathrm{MBM} \mathrm{w} / \mathrm{w}$ (Ct value $38.03 \pm 0.90$ ) or superior amounts were detected as positive by $\mathrm{qPCR}$ tests. When MBM concentrations from 0.20 to 0.40 were added, microscopy analysis was able to detect steamed bone and collagen; whereas if $0.8 \%(\mathrm{w} / \mathrm{w}) \mathrm{MBM}$ was added, steamed bone, collagen and hair could be detected. The qPCR tests showed linear signals for detection of spiked samples with increasing MBM concentrations. Proportional Ct values of $38.03 \pm 0.90,37.13 \pm$ $0.0,34.34 \pm 0.28,33.16 \pm 0.70,30.20 \pm 0.10,29.68 \pm 0.17$ and $27.89 \pm$ 0.08 were obtained for $0.0125 \%, 0.025 \%, 0.05 \%, 0.10 \%, 0.20 \%, 0.40 \%$ and $0.80 \% \mathrm{w} / \mathrm{w} \mathrm{MBM}$, respectively. The Ct values in concentrations above $0.20 \%$ were within the expected value for optimal amplification, generating $\mathrm{Ct}$ values from 20 to 30 . The qPCR tests showed better performance than microscopic analysis in detecting the smallest amount of $0.0125 \%(\mathrm{w} / \mathrm{w}) \mathrm{MBM}$, confirming the difficulty in identifying low concentrations of animal-derived materials in complex feed matrices (Table 3).

Regulation (EC) 999/2001 of the European Parliament and of the Council of 22 May 2001 established rules for the prevention, control and eradication of certain transmissible spongiform encephalopathies [28]. Article 7 of Commission Regulation (EC) 999/2001 prohibits the feeding of certain categories of animal protein to certain categories of animals, and prohibits the inclusion of protein derived from mammals in feeds for ruminants. PAP produced from ruminant carcasses, some of which were infected, was assumed to be the transmission route of BSE. Based on these findings, a ban on the use of processed mammalian protein for feeding cattle, sheep and goats was initiated in July 1994.

Animal material-free feeds spiked with different amounts of MBM were tested by qPCR. The results were compared to those obtained by

\begin{tabular}{|l|l|l|}
\hline Spiked feeds Concentration of MBM (\%) w/w added & qPCR tests for bovine material (Ct-value) & Microscopic analysis \\
\hline 0.0125 & $38.03 \pm 0.90$ & ND \\
\hline 0.025 & $37.13 \pm 0.0$ & Steamed bone \\
\hline 0.05 & $34.34 \pm 0.28$ & Steamed bone \\
\hline 0.10 & $33.16 \pm 0.70$ & Steamed bone \\
\hline 0.20 & $30.20 \pm 0.10$ & Steamed bone and collagen \\
\hline 0.40 & $29.68 \pm 0.17$ & Steamed bone and collagen \\
\hline 0.80 & $27.89 \pm 0.08$ & Steamed bone, collagen and hair \\
\hline
\end{tabular}

Table 3: Comparative detection of MBM in spiked feeds free of animal material by qPCR tests and microscopic analysis. Feedstuff samples free of animal material were spiked with increasing concentrations of MBM, from 0.0125 to $0.80 \% \mathrm{w} / \mathrm{w}$. The Ct-values (mean and standard deviation) were obtained in triplicate PCR reactions from each DNA extraction. ND - animal material not detected.

The ban was expanded in January 2001, prohibiting the feeding of any processed animal protein to all farm animals, with certain limited exceptions. This is to ensure that no cross-contamination occurs between feed containing PAP intended for species other than ruminants and feed intended for ruminants. A Brazilian regulation (Normative Instruction 8, MAPA, promulgated on March 25, 2004) bans the use of products containing proteins and fats of animal origin, including steamed bone, in ruminant feeds [29]. The poorly controlled manufacturing of MBM, as well as low quality control, especially in the
Brazilian countryside, could eventually endanger the health of the national herd, which may affect meat exports and be a source of several diseases, such as botulism and BSE [30,31].

The use of MBM, a low-cost alternative supplement of ruminant feed, is widespread among producers, as a source of phosphorus for farm animals that are raised on pastures with mineral-deficient soil. The calcined bones are sterilized at temperatures above $600^{\circ} \mathrm{C}[32]$. 
Steamed bone is the dried and ground product obtained from undecomposed bones that are heat-treated by autoclaving at temperatures above $140^{\circ} \mathrm{C}$ and pressures greater than 7.0 bar for a minimum of three hours. According to Brazilian regulations, fat and protein residues may or may not be removed during this process [33]. Microscopic analysis is currently the only validated method for detecting animal proteins in feed, including calcined and steamed bones. The discrepancy found between the detection of calcined bones by the qPCR tests and microscopy can be explained by an incomplete calcination process that left biological residues in a sub-product used to supplement feeds with a source of mineral elements.

The microscopic analysis method is able to distinguish the presence of animal-derived constituents, but is unable to quantify constituents of animal origin added to feed or to identify the contaminant species. Several analytical methods including electrophoretic, chromatographic and immunological assays can be used to determine the animal species in a wide array of degraded and processed substrates. Although these methods can identify the origin of species present in raw meats, they are significantly less sensitive in heat-treated materials due to proteolysis and/or alteration of the specific epitopes [34].

The amplification of a specific DNA sequence by PCR provides a rapid, sensitive and specific method for the detection of animal tissues in food and feed [35]. However, many PCR-based methods cannot be used for the detection of MBM, since the high temperatures used in the standard rendering process cause DNA fragmentation, leading to difficulty in obtaining reliable results [36]. The qPCR test used for the detection of species-specific DNA sequences can detect the smallest amounts of even highly degraded DNA. In this study, a qPCR test based on a TaqMan probe was used to detect very small amounts of degraded DNA from five animal species (cow, goat, sheep, pig and chicken). For this purpose, the mitochondrial genome was targeted [37], since it is a robust multi-copy DNA and is still present in meat meals treated at extremely high temperatures.

The present study used soybean and corn seeds as endogenous controls, since these grains usually comprise the major source of protein added to animal feedstuffs. Only sequences of multiple-copies genes were selected. For the analyses involving different vertebrate species, two mitochondrial genes were used: $12 \mathrm{~S}$ rRNA caprine speciespecific and cytochrome $b$ for bovine, ovine, porcine and avian material (chicken). For the endogenous control the tRNA leucine gene was analyzed, which is a sequence present in the chloroplast genome [35].

The material from bovine, ovine and caprine species showed sensitivity equal to or less than $500 \mathrm{pg}$ DNA, which corresponds to $0.01 \% \mathrm{w} / \mathrm{w}$; while for avian (chicken)-derived material the sensitivity was $50 \mathrm{pg}$, which corresponds to $0.001 \% \mathrm{w} / \mathrm{w}$. The precision of the measurement decreased with the number of copies of the target sequence in the genome and harsher conditions during the processing of meat-and-bone meal, which lead to highly fragmented DNA. An alternative is to evaluate the mass concentrated from serial dilutions of each DNA template to establish the method sensitivity, as was conducted in this study [38].

The linearity of DNA detection for all species performed well, with R-squared values of 0.99 and slopes close to the theoretical optimum. This indicates that the results for the quantification of the bovine, porcine, caprine, ovine and avian (chicken) species and also the endogenous controls were reliable. However, these calculations are very challenging, since the amount of DNA per gram of tissue can differ in the reference and sample materials (e.g., tissue, processing, etc.), and the ingredients could be processed in different ways (e.g., cooked meat, but unprocessed fat, etc.), and consequently the response (Ct-values) of one species is not consistent and cannot be compared with those of other species.

In addition, the results of the present study can be carefully extended to different MBM samples and feed materials, since different kind of MBMs could generate a great variation in $\mathrm{Ct}$ values from those reported by this study at the same spike level $(\mathrm{w} / \mathrm{w})$ in feed samples. It is known that the mitochondrial DNA (mtDNA) is a variable and multicopy target (mitochondrial density can vary significantly between different kind of tissues, and, consequently, between derived MBMs).

The microscopy method is able to detect the presence of constituents of animal origin in feed at the level of $1 \mathrm{~g} / \mathrm{kg}$ with hardly any false negatives. Nevertheless, microscopy cannot determine the species of animal matter and requires a skilled operator [22]. Moreover the lower limit of detection of MBM in feeds by microscopic analysis, as mentioned previously, was $0.025 \% \mathrm{w} / \mathrm{w}$; already an interlaboratory study by the European Union reached an upper limit of $0.1 \% \mathrm{w} / \mathrm{w}$ [39]. A study by Sanches and collaborators [21] on the detection and identification of animal-derived material in ruminant feedstuffs found a detection limit of $0.05 \% \mathrm{w} / \mathrm{w}$ for MBM. The detection limit of $0.0125 \%$ achieved by qPCR tests for bovine-derived material, as shown in the present study, is similar to the limit described by Jonker and collaborators, using a different food matrix. These authors presented a method based on qPCR tests for identification of beef, pork, horse, mutton, chicken and turkey materials in processed meat products at the level of $0.01 \% \mathrm{w} / \mathrm{w}$, using a set of primers and species-specific probes. However, the performance of the qPCR tests used in the present study was superior when compared to the results of several other studies in this field. Prado et al. carried out an inter-laboratory study using the TaqMan-qPCR system, which detected the amount of $0.1 \% \mathrm{w} / \mathrm{w}$ bovine MBM or mixtures with different raw materials of animal origin in ruminant feedstuffs, which corresponds to the same detection limit found herein [40]. Brodmann and Moor, compared the sensitivity of TaqMan-qPCR to microscopic analysis in detecting MBM, and concluded that $\mathrm{qPCR}$ tests cannot compete with the microscopic method [38]. A detection limit around $1 \%$ in meat and bone-meal samples may be insufficient to eradicate BSE. To improve the detection limit, further investigation of the DNA extraction method is needed. Martín et al. using a real-time PCR approach with the SYBR Green targeting the mitochondrial 12S rRNA gene for the analysis of experimental bovine tissues in feeds, demonstrated that the assay can detect $0.1 \% \mathrm{w} / \mathrm{w}$ bovine DNA, even after severe heat treatment (up to $133^{\circ} \mathrm{C}$ for $20 \mathrm{~min}$ at $300 \mathrm{kPa}$ ) of the bovine-derived material [41]. Additionally, Cawthraw et al. using feed free from animal material and spiked with MBM generated by a commercial rendering process, showed that $0.1 \% \mathrm{w} / \mathrm{w} \mathrm{MBM}$ could be detected using species-specific real-time PCR assays targeting for $16 \mathrm{~S}$ rDNA [42].

As the production of ruminant feeds involves heat treatment that denatures proteins and DNA, the techniques based on DNA analysis, combined or not with a fluorescent probe (real-time PCR), in addition to requiring undamaged DNA, cannot distinguish different kinds of tissues, since each cell of every tissue in an advanced organism has identical DNA [39]. Although microscopic methods have difficulty in distinguishing mammal from poultry bones and the success in identifying animal structures depends on the expertise of the analyst, this technique is the only test that the Commission of the European 
Communities endorses [25]. In addition, there are many advantages in detecting animal meals in feed by microscopy: the method is unaffected by sample heat treatment, and has accepted detection limits, low cost, simplicity and speed when the operator has experience in identifying animal structures.

Prions are responsible for transmissible spongiform encephalopathies (TSEs) [43]. The infective dose of prions in animal material is another point to consider when analyzing feedstuffs intended for ruminants. Fryer and McLean studied the data and mathematical models that describe scrapie infections in mice following an experimental challenge over a broad range of doses [44]. These authors analyzed data from 4,338 mice inoculated at doses ranging over ten orders of magnitude. These data were compared to the results from a within-host model in which prions accumulate according to a stochastic birth-death process. Crucially, this model assumes no threshold for the dose required to produce infection. The data revealed that even a 1000 -fold dilution of the initial dose was capable of causing a prion infection in half of the challenged animals (ID50). These findings imply that there is no safe dose to prevent a prion infection, and, thus, assessments regarding the risk from a low-dose exposure can correctly assume a linear relationship between the dose and the probability of infection.

The results of this study indicate that, because of their efficiency, represented by specificity and sensitivity, qPCR tests should be included in routine evaluation of feeds in Brazil. Classical microscopic analysis will probably remain the first-line monitoring method, but the qPCR technique should be implemented in the future and could be legally accepted as a complementary method. The combined use of microscopy and qPCR can be important in the discrimination of potential false positive and/or false negative results. The speciesspecific qPCR assays evaluated herein demonstrate potential for use in the rapid and routine detection of the presence of bovine, caprine, ovine, porcine and avian (chicken) MBM in feedstuffs, in order to safeguard the preeminent position of Brazil as a meat exporter.

\section{Acknowledgements}

This paper is dedicated to the memory of Professor D. S. Joab Trajano Silva, with gratitude for his guidance, friendship and dedication during the investigation. We thank the Laboratório Nacional Agropecuário de Minas Gerais (LANAGRO)-National Agriculture and Livestock Laboratories for aiding with the microscopic analysis and for kindly providing the bovine MBM reference samples. We also thank Dr. Cecília Ribeiro from the Fluminense Federal University, Niterói, Brazil for providing the animal blood samples. CAPES and FAPERJ provided financial support.

\section{References}

1. Ribeiro RF (2012) The Ox from the Four Corners of the World: The Historic Origins of the Brazilian Beef Industry. Agrarian South: Journal of Political Economy 3: 315-340.

2. Brasil (2003) Ministry of Agriculture, Livestock and Supply. Approves the standardization of methodology for Byproducts Detection of Animal ingredients in mixtures for Power Ruminants by microscopy.

3. ABIEC (2012) Associação Brasileira das Indústrias Exportadoras de Carne. Brazilian beef profile.

4. Estanislau M, Cançado Jr (2000) Economic aspects of beef cattle, Magazine Tell Agriculture 21: 5-16.

5. Tamminga S (1996) A review on environmental impacts of nutritional strategies in ruminants. J Anim Sci 74: 3112-3124.
6. Schoenian S (2014) Small Ruminant Info Sheet. The truth about grain: feeding grain to small ruminants.

7. Sumption K (2007) Epidemiological Events in 2005-2006. FAO EMPRES (Emergency Prevention System) Focus-On 1: 1-11.

8. Dormont D (2002) Prions, BSE and food. Int J Food Microbiol 78: 181-189.

9. Concepcion GP, Padlan EA (2003) Are humans getting 'mad-cow disease' from eating beef, or something else. Med Hypotheses 60: 699-701.

10. Plews M, Lamoureux L, Simon SL, Graham C, Ruddat V, et al. (2011) Factors affecting the accuracy of urine-based biomarkers of BSE. Proteome Sci 9: 6.

11. World Health Organization (1996) Report of a WHO consultation on public health issues related to human and animal transmissible spongiform encephalopathies with the participation of FAO and OIE, Geneva. World Health Organization.

12. Mathews KH, Vandeveer M, Gustafson RA (2006) An Economic Chronology of Bovine Spongiform Encephalopathy in North America/ LDP-M-143-01 Washington, DC: Economic Research Service/ USDA, Electronic outlook report from the economic researchService/USDA.

13. Brasil (2008) Ministry of Agriculture, Livestock and Supply. Approves the Technical Regulation of Sanitary Hygienic Inspection and Technology of Animal Waste Processing and Model Waste Animal Transport Document in Annexes I and II, respectively.

14. Winterø AK, Thomsen PD, Davies W (1990) A comparison of DNAhybridization, immunodiffusion, countercurrent immunoelectrophoresis and isoelectric focusing for detecting the admixture of pork to beef. Meat Sci 27: 75-85.

15. Fumière O, Dubois M, Baeten V, von Holst C, Berben G (2006) Effective PCR detection of animal species in highly processed animal byproducts and compound feeds. Anal Bioanal Chem 385: 1045-1054.

16. Van Raamsdonk LWD (2007) New developments in the detection and identification of processed animal proteins in feeds. Anim Feed Sci Technol 133: 63-83.

17. Niederer M, Bollhalder R (2001) Identification of species specific central nervous tissue by gas chromatography-mass spectrometry (GC-MS) A possible method for supervision of meat products and cosmetics. Mitteilungen aus dem Gebiete der Lebensmitteluntersuchung und Hygiene 92: 133-144.

18. AOAC (1998) Association of Official Analytical Chemists, Official method. Microscopy of animal feed, Gaithersburg, MD.

19. Arya M, Shergill IS, Williamson M, Gommersall L, Arya N, et al. (2005) Basic principles of real-time quantitative PCR. Expert Rev Mol Diagn 5: 209-219.

20. Prado M, Fumière O, Boix A, Marien A, Berben G, et al. (2009) Novel approach for interlaboratory transfer of real-time PCR methods: detecting bovine meat and bone meal in feed. Anal Bioanal Chem 394: 1423-1431.

21. Sanches RL, Alkmin-Filho JF, De Souza SVC, Junqueira RG (2006) Inhouse validation of a method for detection of animal meals in ruminant feeds by microscopy, Food Control 17: 85-92.

22. Liu X, Han L, Veys P, Baeten V, Jiang X, et al. (2011) An overview of the legislation and light microscopy for detection of processed animal proteins in feeds. Microsc Res Tech 74: 735-743.

23. Huss W (1975) Microscopy and quality control in the manufacture of animal feeds. Hohenheim: Roche.

24. AAFM (1992) American Association of Feed Microscopists. Manual of microscopic analysis of feedstuffs pp: 113- 145.

25. Comission of the European Communities (1998) Commission Directive 98/99/EC of 13 November 1998 establishing guidelines for the microscopic identification and estimation of constituents of animal origin for the official control of feedingstuffs, Official Journal of the European Communities 318: 0045-0050.

26. Juusola J, Ballantyne J (2007) mRNA profiling for body fluid identification by multiplex quantitative RT-PCR. J Forensic Sci 52: 1252-1262. 
Citation: Golinelli LP, Silva JT, Carvalho AC, Paschoalin VMF (2016) Detection of Animal Products in Ruminant Feeds by Microscopy and Real Time PCR. J Veterinar Sci Techno 7: 316. doi:10.4172/2157-7579.1000316

Page 7 of 7

27. Radoni $¥$ $\ddagger$ A, Thulke S, Mackay IM, Landt O, Siegert W, et al. (2004) Guideline to reference gene selection for quantitative real-time PCR. Biochem Biophys Res Commun 313: 856-862.

28. Commission Regulation (EC) (2001) Laying down rules for the prevention, control and eradication of certain transmissible spongiform encephalopathies. Pp: 147: 1-40.

29. Brasil (2004) Ministry of Agriculture, Livestock and Supply Regulatory Instruction No. 7 of 17 March 2004 prohibits the importation of ruminants, their products and by-products for any purposes, and products for veterinary use which contain in their composition inputs derived from ruminants in originating in or coming from high-risk countries by SDA. Official Gazette of the Union Brasilia.

30. Döbereiner J, Tokarnia CH, Langenegger J, Dutra IS (1992) Epizootic botulism of cattle in Brazil. Dtsch Tierarztl Wochenschr 99: 188-190.

31. Bliska FMM (2001) Considerations Bovine Spongiform Encephalopathy and Brazilian beef exports. National Beef Magazine 288: 100.

32. Ooi CY, Hamdi M, Ramesh S (2007) Properties of hydroxyapatite produced by annealing of bovine bone. Ceram Int 33: 1171-1177.

33. Brasil (2007) Ministry of Agriculture, Livestock and Supply. Instruction No. 5 of 23 February 2007 approves the definitions and rules on the specifications and warranties, tolerances, registration, packaging and labeling of mineral fertilizers used in agriculture, Official Gazette of Brasilia Union, DF.

34. Hofmann K (1996) Proof of proper heating of meat and bone meals, Fleischwirtschafte, 76: 1037-1039.

35. Benedetto A, Abete MC, Squadrone S (2011) Towards a quantitative application of real-time PCR technique for fish DNA detection in feedstuffs. Food Chem 126: 1436-1442.
36. Colgan S (2001) Development of a DNA-based assay for species identification in meat and bone meal. Food Res Int 34: 409-414.

37. Dalmasso A, Fontanella E, Piatti P, Civera T, Rosati S, et al. (2004) A multiplex PCR assay for the identification of animal species in feedstuffs. Mol Cell Probes 18: 81-87.

38. Brodmann PD, Moor D (2003) Sensitive and semi-quantitative TaqManâ,„ $₫$ real-time polymerase chain reaction systems for the detection of beef (Bos taurus) and the detection of the family Mammalia in food and feed. Meat Sci 65: 599-607.

39. Momcilovic D, Rasooly A (2000) Detection and analysis of animal materials in food and feed. J Food Prot 63: 1602-1609.

40. Prado M, Berben G, Fumière O, van Duijn G, Mensinga-Kruize J, et al. (2007) Detection of ruminant meat and bone meals in animal feed by real-time polymerase chain reaction: result of an interlaboratory study. J Agric Food Chem 55: 7495-7501.

41. Martín I, García T, Fajardo V, Rojas M, Hernández PE, et al. (2008) Realtime PCR for quantitative detection of bovine tissues in food and feed. J Food Prot 71: 564-572.

42. Cawthraw S, Saunders GC, Martin TC, Sawyer J, Windl O, et al. (2009) Real-time PCR detection and identification of prohibited mammalian and avian material in animal feeds. J Food Prot 72: 1055-1062.

43. Curcio L (2015) PRNP polymorphisms in four Italian sheep breeds. Livest Prod Sci 181: 38-42.

44. Fryer HR, McLean AR (2011) There is no safe dose of prions. PLoS One 6: e23664. 